\title{
Balancing quantitative and qualitative value-creation reporting
}

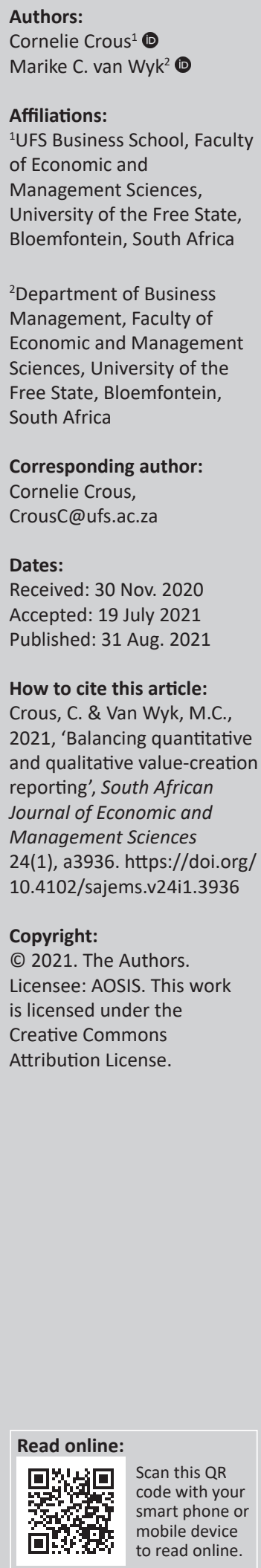

Method: The demand for a balanced disclosure of quantitative and qualitative value creation in an organisation and for its stakeholders has increased in recent years.

Aim: Therefore, this study focused on the disclosure of 97 companies listed on the Johannesburg Stock Exchange over a period of five years (2015-2019).

Method: A three-phased content anlaysis was followed.

Results: The researchers found that value-creation disclosures are mostly concerned with quantitative value creation, and that they focus on value concepts, such as returns to investors, cash flow, increase in employee numbers, and benefits to employees. Some companies have progressed in their integrated reporting practices and now include a reference to value creation by balancing the different forms of capital. However, their reports still do not include concrete statements or definitions about what value creation is considered to be; neither do they disclose qualitative value-creation concepts.

Conclusion: The authors thus conclude that imbalanced reporting skewed towards quantitative value concepts persists.

Keywords: integrated reporting; value creation; qualitative value creation; quantitative value creation; stakeholders.

\section{Introduction}

Since the issue of the first International Integrated Reporting Framework (IRF) in 2001, international debates have continued about the concept of value creation, its meaning and how best to define it, the processes involved in creating value, whom value is created for, and how companies should report on these concepts. Conventional approaches to value in an organisation can be found in strategic management literature in the works of authors such as Freeman (2001) and Porter (1980). Terms such as 'use-value' and 'exchange value' are traditionally linked to value from a consumer perspective, and later research links value creation to the value an organisation creates for shareholders.

Traditional corporate reporting focused on the concept of value creation as financial value for investors and shareholders, thus focusing on shareholder-centred reporting and concepts such as profit, reduction in costs, cash flow, and market metrics (Glassman, Potoski \& Callery 2017; Schoenmaker \& Schramade 2019; Sheveleva 2018; Sofian 2018). The IRF, however, indicates that value is not only created for the organisation and its investors, but for other stakeholders as well (International Integrated Reporting Council [IIRC] 2013).

Other stakeholders, recognised in the literature, include employees (also referred to as human capital), society or communities (social capital), customers, and the company boards to a limited extent. The value created for these stakeholders is almost always related to economic or financial aspects. Value for customers is defined either as products or services provided to them, or as the reduced costs of products (Freudenreich, Ludeke-Freund \& Shaltegger 2019; IFAC 2020). Value creation for employees is linked to salaries, benefits, and number of employment opportunities created in the form of employee numbers (IIRC 2017; Sunder 2017). However, several authors acknowledge that the aspects of non-financial value creation or qualitative value creation for employees, such as job satisfaction, job quality, and the impact of leadership on the morale and behaviour of employees are challenging to define and thus do not receive the much-needed attention in corporate reporting (Freudenreich et al. 2019; IIRC 2017; Lev \& Sunder 1979).

The value created for company boards, similar to that of customers, can be qualitative in nature. This qualitative value could include a better understanding of risks and opportunities facing the 
organisation, building trust and relationships, a clearer articulation of strategy, and enhancement of their governance role (Adams 2017; IIRC 2014). Value for society or communities is often equated with Corporate Social Responsibility (CSR) expenditure or shared value (Gokten \& Gokten 2017; Sheveleva 2018; Sofian 2018) to the exclusion of qualitative aspects, such as social licencing, legitimacy to operate, and cultural relationships and beliefs (Freudenreich et al. 2019; Gokten \& Gokten 2017).

From the extant literature mentioned above, it is clear that value creation is not only a quantitative or economic concept, but should also include qualitative or non-financial aspects (Freudenreich et al. 2019; IIRC 2017; Lev \& Sunder 1979; Gokten \& Gokten 2017; Sofian 2018; Sheveleva 2018). The international focus on financial value, sometimes to the exclusion of qualitative or non-financial value, warrants investigation. Beyond the literature, the definition of value creation among companies issuing integrated reports demonstrate an overall focus on the quantitative value creation to the exclusion of qualitative value creation.

This article is aimed at stimulating the debate on what is implied by the term value creation, with reference to both quantitative and qualitative value-creation concepts. By analysing the extant literature, we demonstrate focus on the overarching quantitative value creation and only minimally on qualitative value-creation concepts. We demonstrate the quantitative emphasis through an analysis of published reports by environmentally sensitive companies listed on the Johannesburg Stock Exchange (JSE) between 2015 and 2019.

The article continues with a literature review providing an overview of the development of the term value creation in strategic management literature. This is followed by a discussion on how both qualitative and quantitative value creation have been defined for different stakeholders in literature. The results of the analysis of the integrated reports of the listed companies will then be presented, while recommendations for further research concludes the article.

\section{Literature review Overview of the development of the term value creation}

Value creation has not only been a key concept in financial and management literature for decades, it also remains a quintessential objective performance measure for organisations across the board (Sheveleva 2018). The goal of any organisation is to deliver value to its investors (Knight 2002), as well as ultimately to maximise its shareholder value (Sacui \& Dumitru 2014) through an array of operational, financial and investment policies (Burcă \& Cilan 2016) in line with the shareholder value perspective.

There is no single universal definition that scholars agree on for the complex multi-dimensional construct that is value creation. Often the discipline and focus of theory and research determine the vantage point from which the term is considered. However, the general interpretation of value in a business context is economical, in that companies create value for their shareholders that is quantifiable in monetary terms (Sheveleva 2018). Bowman and Ambrosini (2000) proposed that a clear distinction be made between use value and exchange value. In an attempt to arrive at a broad definition of value creation, and drawing on the work of Bowman and Ambrosini, Lepak, Smith and Taylor (2007:190) they defined value creation as 'the difference between use and exchange value that can apply to all levels of analysis'.

From a fundamental consumer perspective, use value refers to consumers' individual - and therefore subjective - assessment of product or service qualities in relation to their personal needs, that is perceived value (Bowman \& Ambrosini 2000). Perceived value can be construed as a qualitative measure, and may include aspects such as customer satisfaction, retention and loyalty, which will be discussed later in this article. Exchange value refers to the monetary value due to consumers, or quantitative aspects, at the exact point of 'exchange' or purchase in order to obtain a product or service (Bowman \& Ambrosini 2000).

From their resource-based stance, Bowman and Ambrosini (2000) reiterated that value could only be created once inert resources - tangible and intangible alike - are subjected, through human intervention, to a production process in which the resources are activated, developed, and made operational. It was held that only through the subjugation of the values acquired by the firm, that is resources, to a transformation process could new use value ultimately be created. This, in essence, limited the extent to which any organisation could add value to that which was ultimately owned by the organisation. In this context, the emphasis is on strategy, according to the work of Porter (1980:xv), who reiterates that the value of resources and capabilities is inextricably bound with strategy'.

The proposition of generic and corporate strategies by Porter (1980) is central to deconstructing the notion of value creation. Generic strategy pertains to the creation of a competitive advantage within the industry it competes in so as to create optimal value for both the individual consumer and the organisation. Value is added to benefit the individual consumer through a trade-off between the benefits and sacrifices, as perceived by the consumer, in line with the previous example of use and exchange value (Bowman \& Ambrosini 2000). Inversely, consumers add value through the trade-off between the benefits and sacrifices as perceived by the organisation. According to Porter (1980), creating value for customers, at least on an individual level, suggests: (1) increased effectiveness through differentiated treatment, based on the individual consumer's needs, value and potential; (2) efficient and effective processes; (3) better margins; and (4) increased relevance and reduced reaction time.

Corporate strategy is concerned with improving shareholder value, the maximisation of long-term profitability and, ultimately, the value of the organisation. This is achieved not 
only through competing in the relevant industries and the number of business, but also through adding value synergistically and sustainably. In essence, corporate strategy enables organisations to pursue new strategic avenues that ultimately hold the potential to increase the value for the shareholder and the value of the organisation. From this vantage point, the primary strategies, defining value, rest on both internal (investigation and selection of additional strategic avenues within the organisation), and external business endeavours (mergers, acquisitions and alliances).

The notion of value creation has, however, gone through a transformational process of its own over the years, in which the initial definition evolved from one that was primarily concerned with financial capital to one that now acknowledges that value is 'multi-capital and multi-dimensional' (IIRC 2013:10). The evolution of value-creation concepts is a result of how they allow an enhanced understanding of the changing values, priorities, and strategy-identifying approaches of organisations over the years (Sheveleva 2018). In their review of the evolution of value creation, specifically in the field of strategy, Ramaswamy and Ozcan (2013) point out that it was not until the 1980s that organisations began to change how they viewed the process of value creation. This emerged in the work of authors such as Barney (1991) and Wernerfelt (1984). Smaller competitors with less access to resources began to outmanoeuvre and successfully compete with larger organisations. In examining this phenomenon, three fundamental causes, related to resources, from which ultimately value creation emerged: (1) resources are not only financial and physical but also intellectual; (2) resources are mutually interchangeable, and through the strategic use of joint ventures and alliances, the resources of external parties can innovatively be leveraged; and (3) the starting point has to be the realisation that strategy is about the efficient and effective use of resources 'whether reusing and redeploying core competencies in new applications across businesses or changing industry norms' (Ramaswamy \& Ozcan 2013:7). These assumptions led to senior management shifting its focus away from being mere resource allocators to becoming the leveragers of corporate resources.

As a result of smaller firms' relationships and alliances with external parties, and their access, consequently, to an entire resource base, the concept of value creation evolved from being limited to internal resources and competencies to a significantly broader idea of what the organisation owned. The notion of a global resource base is also in line with Porter's (1989) emphasis on the importance of capturing the benefits of relationships between businesses and business units in order to create synergy and ultimately increase the value creation of the organisation.

Up until this point, the responsibility for creating value was still solely that of the organisation itself. The different forms of value created - whether on a corporate level (shareholder value) or an individual consumer level (perceived value) were financial. All of this was, however, disrupted at the turn of the century as (1) customers increasingly became a source of talent, knowledge and competence (Ramaswamy \& Ozcan 2013); and (2) the call for a new model for conducting business emerged (Porter \& Kramer 2019).

The concept of Creating Shared Value (CSV) was suggested as a model that would ultimately bridge the gap between business and society brought on by the value perspective of the shareholders' narrow-minded pursuit of short-term profits at the expense of the broader community. The notion of CSV is concerned with the generation of economic value in a manner that also brings about value for society at large by addressing its unique challenges (Porter \& Kramer 2019; Windsor 2017). The use of CSV as a proxy for value creation has, however, been criticised due to its ideological similarity to CSR and its philanthropic goals with little or no profit maximisation or value creation for society (Komonen 2019; Sheveleva 2018). As Windsor (2017:81) states: 'CSR activity remains costless to the firm, which may enjoy reputational benefits', as the organisation is responding to social requests rather than behaving responsibly.

Regardless of the critique, the CSV approach brought an increase in organisations' competitiveness, while the social and economic conditions of the communities in which organisations conduct their business were uplifted. Suddenly, the scope of value creation was broadened and challenged to move beyond mere financial (quantitative) value creation to include elements of shared value and non-financial (qualitative) value creation. Non-financial, qualitative value creation instils trust and confidence as it is directly associated with management strategy and the environmental context that guides the decision-making process (Burcă \& Cilan 2016).

\section{Value creation for different stakeholders}

Now more than ever, organisations are aware of the importance of addressing the needs and expectations of a diverse and ever-increasing number of interest groups (Sheveleva 2018). This results in the focus ultimately shifting from a shareholder perspective to a stakeholder perspective. Stakeholders are 'groups and individuals who benefit from or are harmed by, and whose rights are violated or respected by, corporate actions' (Freeman 2001:59). The rationale for stakeholder engagement is rooted in the possible advantages and additional value that can be derived from this endeavour as a result of greater trust in the organisation based on increased accountability and transparency. Sheveleva (2018) emphasises the need for effectively integrated stakeholder thinking as this is the only way in which sustainable stakeholder value can be created. The question remains, however, as to how this value can and should be defined.

According to Windsor (2017:76), the concept of value 'lacks theoretical precision and empirical verification'. Although the concept has developed in the management and strategy disciplines, there is little agreement among scholars on its definition. One definition of value is 'the surplus or gain in someone's welfare relative to a previous condition', alluding to a quantitative economic concept (Windsor 2017:76). 
The IRF (IIRC 2013) conceptualises value as twofold: for the organisation, and for other stakeholders. The value created for the organisation itself pertains to the organisation's obtained financial returns that are transferred to the shareholders, while value created for others pertains to more abstract concepts, such as relationships, endeavours and interactions (Sheveleva 2018). Both of these concepts include objective (quantitative) and subjective (qualitative) aspects.

Furthermore, the IRF links value creation closely to the six capitals. By recognising the interconnectedness of the six capitals (financial, manufactured, human, relational, natural, and intellectual) and understanding how to balance these capitals within an organisation, management could create value in the short, medium and long term for all stakeholders (IFAC 2020; Sheveleva 2018). This interconnectedness denotes complex relationships which rest on more than just economic and quantitative aspects for both the organisation and other stakeholders.

Value to the organisation lies in the profitability of the organisation (Barnabe, Giorgino \& Kunc 2019; Freudenreich et al. 2019; Śledzik 2013). This approach to defining value is related to the shareholder and agency theories in which management creates value for shareholders and the organisation, among others, in the form of profits, increased cash flow and Return on Investment (ROI), as well as reduced costs, fixed asset investments and taxes (Dalbøl \& Dalbøl 2011; Karia 2019; Śledzik 2013). On the other hand, value for others is linked to the stakeholder theory according to which an organisation should consider the legitimate needs of different stakeholder groups to ensure the sustainability of the organisation (Acciaro 2015). Additionally, scholars argue that value is only created for others if an organisation does manage the relationships effectively, as well as appreciate the active contribution of the stakeholders (Freudenreich et al. 2019; Komonen 2019).

Identifying multiple stakeholders and their contributions to an organisation is not an easy task. Value-creation literature commonly focuses on investors as the primary stakeholders (Adams 2017; Barnabe et al. 2019; Freudenreich et al. 2019; Glassman et al. 2017; Gokten \& Gokten 2017; Sheveleva 2018; Śledzik 2013), and to a lesser extent on other stakeholders, such as employees, the board of directors, suppliers, customers, and society or communities at large. Determining the quantitative (objective) value an organisation creates for each group seems the prevalent method of defining value for each group. Identifying qualitative (subjective) value is, however, more complicated.

As providers of capital to organisations, authors identify investors as the primary stakeholders in any organisation. As such, the majority of the value-creation literature focuses on how value is defined and created for them (Adams 2017; Barnabe et al. 2019; Freudenreich et al. 2019; Grassman, Fuhrmann \& Guenter 2019; Śledzik 2013). Flower (2015) and Cheng et al. (2014) criticised the IRF for promoting practices that allowed organisations to focus their reporting on the providers of capital to the exclusion of other stakeholders. Statements in the IRF, such as 'IR aims to improve the quality of information available to the providers of financial capital to enable a more efficient and productive allocation of capital' (IIRC 2013:2), as well as the statement, 'The ability of an organization to create value for itself enables financial returns to the providers of financial capital' (p.4), certainly support this argument.

Value to customers is often expressed as providing goods and services at affordable prices and better resource allocation to reduce related costs (Freudenreich et al. 2019). The qualitative value related to customers, such as customer satisfaction and customer loyalty, is not addressed in extant value-creation literature except for linking value back to the organisation as increased profits and cash flows (Dalbøl \& Dalbøl 2011; Śledzik 2013; Titko \& Shina 2017). The emotional value created (how customers feel) is either not recognised by management or not considered to be relevant to purposes of reporting.

Similarly, the value created for employees, in the form of human capital, is often reflected in company reports and literature with quantitative measures, such as the number of hours worked, financial benefits received, rewards schemes, and education provided (Gokten \& Gokten 2017; Śledzik 2013; Sunder 2017; Titko \& Shina 2017). The qualitative value an organisation creates for employees, such as quality leadership, low employee turnover, staff morale, employeedriven innovation, institutional knowledge, fair staff policies, productivity, skills level and capabilities are recognised in the human-capital literature only. Value-creation literature, however, excludes these concepts as they are seen to be emotional and not directly linked to financial performance (Adams 2017; Gokten \& Gokten 2017; IIRC 2017; Karia 2019; Śledzik 2013; Sunder 2017).

Social value is linked to the competitive advantage gained from the 'sustainable development of markets and society' (Freudenreich et al. 2019:3). This relationship, unlike that of customers, suppliers and employees, is not governed by an economic contract. Social value creates a stable operating environment for an organisation in which to operate and results in legitimising its operations and granting the organisation a social licence to operate (Freudenreich et al. 2019; Gokten \& Gokten 2017). Gokten and Gokten (2017) argue that social value is not easy to identify and define as it includes non-financial aspects, such as social and political pressure and mutual trust between the organisation and society.

\section{Research method}

Because companies trading in environmentally sensitive industries tend to issue higher-quality non-financial reports to improve their reputation (Azapagic 2004; Cho \& Patten 2007; Christian 2016; De Villiers \& Alexander 2014; Farneti \& Guthrie 2009; Maubane, Prinsloo \& Van Rooyen 2014), all companies listed on the JSE in environmentally sensitive industries were selected. These industries include Chemicals, 
Construction and Material; Forestry and Paper; Industrial Metals and Mining;Mining, Oil and Gas; and Pharmaceuticals. A total of 97 companies were identified, of which only 65 issued integrated reports over a six-year period. The study focused on analysing the published Integrated and Annual Reports for these companies in the period 2014 to 2019. In some cases, companies issued both an Integrated, as well as an Annual Report. In these cases, both reports were analysed.

The Integrated Reports and Annual Reports all included detailed financial statements prepared according to International Financial Reporting Standards (IFRS). The financial statements include profits, cash flow, salaries, return on investment and other quantitative benefits to shareholders. The financial statements were used as a proxy for quantitative value creation, and financial capital disclosure and no detailed analysis was performed.

A three-phase content analysis was conducted. In the first phase, the Atlas.ti program was used, and an automated code was created to search the reports for the use of the term value creation. The results are reflected in Table 1 . The second phase involved a detailed analysis of each occurrence of the term to identify any explanation or definition provided by the sampled companies. The third phase of the analysis used Atlas.ti again to summarise the number of occurrences in which the term value creation occurred in conjunction with the qualitative aspects in the reports. A co-occurrence table was generated and is presented in Table 2 .

\section{Findings and discussion}

A total of 594 reports were analysed for the 97 companies in the sample. The term value creation was used a total of 1058 times over the 6-year period. Table 1 summarises the results from phase one of the data analysis.

The search yielded between 65 (2019) and 473 (2017) instances of value creation per year across all the reports. In 2017, the term was used 102 times in a single report. The increased use of the term indicates that these companies became increasingly aware of their responsibility to report on the value they created between 2014 and 2017. From 2018, the number of times the term was mentioned in a single report decreased significantly to a maximum of nine times in 2018 and eight times in 2019.

Although there was a decrease in the use of the term value creation, five aspects that require further consideration in a detailed analysis of the published reports were identified.

Firstly, several companies linked their value creation to the IRF and the use of the six capitals. The concept 'six capitals'

TABLE 1: Number of occurrences of the term 'value creation' per year.

\begin{tabular}{lcccccc}
\hline Variable & $\mathbf{2 0 1 4}$ & $\mathbf{2 0 1 5}$ & $\mathbf{2 0 1 6}$ & $\mathbf{2 0 1 7}$ & $\mathbf{2 0 1 8}$ & $\mathbf{2 0 1 9}$ \\
\hline Total number of reports analysed & 114 & 106 & 119 & 115 & 75 & 65 \\
$\begin{array}{l}\text { Total number of occurrences of } \\
\text { the term value creation }\end{array}$ & 104 & 152 & 228 & 473 & 36 & 65 \\
$\begin{array}{l}\text { The highest number of } \\
\text { occurrences in a single report }\end{array}$ & 10 & 11 & 32 & 102 & 9 & 8 \\
\hline
\end{tabular}

occurred 724 times over the six-year period. This practice demonstrates a positive move towards considering the balance between the capitals and recognising their complex interrelatedness (IFAC 2020; Sheveleva 2018). BHP Billiton (2019:11), for example, included a statement in their 2019 Integrated Report under the explanation of their operational model that states: 'We have a simple and diverse portfolio of tier one assets around the world, with low-cost options for future growth and value creation'. Gold Fields (2019:1) stated that they 'embrace integrated thinking and [take] an integrated approach to value creation, which aligned with the IIRC six capital model'. Although these statements refer to the IRF and value creation, they are general in nature and do not provide a definition of how these companies quantify or qualify value creation.

Similarly, Adcock Ingram (2018) refers to the six capitals and relationships in their value-creation statement while including reference to stakeholders:

When making decisions on how to manage and grow the business, we consider those resources and relationships that are critical to our ability to create value. Input from each of the six capitals is needed for the effective management and subsequent value creation for all our stakeholders. (p. 10)

Exxaro Resources (2018) also references the six capitals and links the balancing of these capitals to sustainable growth and benefits for stakeholders, without providing a specific definition of what they consider the value they create to be:

Exxaro uses the six-capitals model (natural, human, social, manufactured, intellectual and financial capital) as a balanced approach to increase our potential to invest and develop for sustainable growth ... to maximise the benefit to all stakeholders, internally and externally. (p. 8)

Secondly, the majority of companies relate value creation in the integrated reports to financial or quantitative value, in

\begin{tabular}{lcc} 
TABLE 2: Co-occurence of 'value creation', qualitative and quantitative concepts. \\
\hline $\begin{array}{l}\text { Concept used in conjunction } \\
\text { with 'value creation' }\end{array}$ & $\begin{array}{c}\text { Co-occurrence with } \\
\text { 'value creation' }\end{array}$ & $\begin{array}{c}\text { Total occurrence } \\
\text { in all reports }\end{array}$ \\
\hline Qualitative & 12 & 547 \\
Staff retention & 108 & 3641 \\
Skills development & 257 & 11306 \\
Employees and staff & 84 & 5501 \\
Customers & 0 & 29 \\
Customer retention & 0 & 32 \\
Customer loyalty & 64 & 894 \\
Satisfaction & 264 & 6531 \\
Society & & \\
Quantitative & 22 & 321 \\
Return on asset & 4 & 69 \\
Profitibility growth & 82 & 1101 \\
Shareholders return & 32 & 1097 \\
Investors & 40 & 471 \\
Sustainability growth & 110 & 9337 \\
Cash & 77 & 724 \\
Six capitals & 86 & 3627 \\
Dividends & 58 & 1039 \\
Return on capital & &
\end{tabular}


keeping with the main focus in the literature on value creation (Burcă \& Cilan 2016; Porter 1980; Ramaswamy \& Ozcan 2013; Sacui \& Dumitru 2014; Sheveleva 2018; Windsor 2017). This is demonstrated by the inclusion of the financial statements prepared according to IFRS and the mention of quantitative aspects in the narrative descriptions of value creation. Return on assets $(n=321)$, Return on capital ( $n=1039)$, Dividends $(n=3627)$, Profitability growth $(n=69)$, Cash $(n=9337)$ and shareholders' returns $(n=1101)$, occurring mostly in the narrative descriptions, are all linked to quantitative value creation and placed additional focus on the quantitative information contained in the financial statements.

This emphasis on financial and quantitative value creation demonstrates the companies' focus on shareholders and investors as primary stakeholders to the exclusion of other stakeholders (Adams 2014; Barnabe et al. 2019; Freudenreich et al. 2019; Grassman et al. 2019; Śledzik 2013). The company Accentuate (2019) relates value creation to profitability growth; Lonmin relates it to shareholders' return (Lonmin 2016:2); and Pan African Resources (2015:5) relates it to 'share price performance, sustainable earnings, cash flow growth and by consistent dividend payment'. Another example is the use of metrics to quantify value creation in the 2019 Integrated Annual Report by African Rainbow Minerals (2019):

Underpinned by metrics that measure the sustainability of value creation for stakeholders (minimum rate of return; other hurdle rates; payback periods; return on assets; return on capital employed; dividend pay-out/cover ratio, etc). (p. 1)

Thirdly, companies acknowledge the value they create for customers in the products and services they offer $(n=84$ occurrences linked to value creation), supporting the literature that emphasises value to customers as quantitative in nature (Bowman \& Ambrosini 2000; Freudenreich et al. 2019; Porter 1980; Sheveleva 2018; Śledzik 2013; Titko \& Shina 2017). Omitted from the integrated reports is the acknowledgement that value creation to customers also includes qualitative values, such as loyalty ( $n=0$ linked to value creation) and customer retention ( $n=0$ linked to value creation) (Bowman \& Ambrosini 2000; Dalbøl \& Dalbøl 2011; Titko \& Shina 2017). This qualitative focus on products and services is demonstrated by African Oxygen (Afrox) (2019:12) in their Integrated Report, where they state: 'Value creation at Afrox is the sustainable and effective delivery of products and services to add value for its customers in a profitable manner'.

Fourthly, although companies recognise the importance of society in their value-creation process $(n=264$ linked to value creation), only two companies include social value or social licence to operate in their value-creation definition in integrated reports. In their 2016 Integrated Report, ArcelorMittal (2016) equated social-value creation with the Broad-Based Black Economic Empowerment (BBBEE) initiatives of the company and their business incubation project, not really defining qualitative value to society.
Only one company seemed to acknowledge that social value is linked to qualitative aspects, such as relationships. Anglo American Platinum (2017) states:

Our social licence to operate is highly dependent on our ability to demonstrate value creation to host communities and thus a positive impact on social capital. All our activities impact on social capital - the resources and relationships provided by people and society. These impacts can be described as the extent to which a company's actions or decisions contribute positively or negatively to a change in the welfare, capabilities, relationships or livelihoods of people living in society. (p. 30)

Finally, defining qualitative value created for employees, such as providing quality leadership and fair staffing policies, is overlooked when preparing integrated reports (Adams 2017; Gokten \& Gokten 2017; Śledzik 2013; Sunder 2017). The value created for employees is quantified and, more often than not, reported as the investments in skills development $(n=108)$, staff or employee loyalty $(n=16)$ and education or the number of job opportunities created. Wesizwe Platinum (2014), for example, reported its goal of employing an estimated 3300 people by 2021.

The absence of qualitative value creation is even more concerning when compared to the risks disclosed in the integrated reports. Only 16 reports included staff retention and human capital as high-risk areas for the companies. This pattern is manifestly challenging for companies, as it appears that human capital and related value creation are not central concerns for South African listed companies.

\section{Conclusion}

The concept of value creation is not a novel one and has enjoyed much attention from financial and strategic management scholars, such as Porter (1980) and Freeman (2001). The concept, however, evolved from focusing on shareholder value to one that also includes consideration of the value added to other stakeholders. Traditionally, in most of the literature, the term value creation is defined on a quantitative level in terms of maximising profits for shareholders. Value for other stakeholders is also often quantitatively expressed as the use value for customers, benefits to employees, and CSR expenditure in relation to communities.

Despite criticism of the continued focus on quantitative value creation in the IRF since its introduction, scholars have used this document to define and research the concept of value creation. The literature suggests that by considering the legitimate needs and contributions of stakeholders, organisations may determine qualitative value creation, such as customer satisfaction, staff retention, institutional memory, and staff focus on innovation which leads to increased legitimacy and social licence to operate (Freudenreich et al. 2019; Gokten \& Gokten 2017; Śledzik 2013).

Regardless of the increasing focus on qualitative value-creation concepts in the literature mentioned above, our findings suggest that JSE-listed companies still do not sufficiently address or define non-financial and qualitative value creation. 
The reporting themes identified in the data analysis clearly show a propensity for quantifying value creation in Integrated Reporting. This pattern continues in the reporting on value creation for customers, which is linked to products and services offered, the societal value linked to legislative requirements and BBBEE, and value for employees linked to remuneration and number of jobs created. Perhaps the focus on quantitative value is driven by the need to receive the greatest external interest, or perhaps the omission of qualitative value creation aspects in Integrated Reporting is due to the uncertainty by report preparers on what exactly non-financial value creation is. Either way, it is clear that more research is needed into how organisations, report preparers, and users of integrated reports perceive qualitative value creation.

\section{Acknowledgements Competing interests}

The authors have declared that no competing interest exist.

\section{Authors' contributions}

All authors contributed significantly to the conceptualisation, design, drafting and approval of the final manuscript. C.C was the project leader. M.C.V.W. was responsible for the literature on value creation from a strategic management persepctive. C.C. incorporated the aforementioned literature into the Integrated Reporting Literature, and conducted the data anlaysis and interpretation. Both authors conducted the final review and approval of the article before publication.

\section{Ethical considerations}

This article followed all ethical standards for research without direct contact with human or animal subjects.

\section{Funding information}

This research received no specific grant from any funding agency in the public, commercial, or not-for-profit sectors.

\section{Data availability}

Data sharing is not applicable to this article as no new data were created or analysed in this study.

\section{Disclaimer}

The views and opinions expressed in this article are those of the authors and do not necessarily reflect the official policy or position of any affiliated agency of the authors.

\section{References}

Accentuate, 2019, Integrated Annual Report 2019, viewed 28 August 2020, from http://www.accentuateltd.co.za/pdf/financials/57-Accentuate-AnnualReport-2019.pdf.

Acciaro, M., 2015, 'Corporate responsibility and value creation in the port sector', International Journal of Logistics Research and Applications 18(3), 291-311, viewed 4 May 2020, from https://doi.org/10.1080/13675567.2015.1027150

Adams, C.A., 2014, 'The international integrated reporting council: A call to action', Critical Perspective on Accounting 27, 23-28, viewed 28 August 2020, from https://doi.org/10.1016/j.cpa.2014.07.001
Adams, C.A., 2017, 'Conceptualising the contemporary corporate value creation process', Accounting, Auditing and Accountability Journal 30(4), 906-931. https:// doi.org/10.1108/AAAJ-04-2016-2529

Adcock Ingram, 2018, Integrated report 2018, viewed 28 August 2020, from https:// www.adcock.co.za/Content/pdf/Adcock_IAR_2018.pdf.

African Oxygen (Afrox), 2019, Integrated report 2019, viewed 28 August 2020, from http://www.afrox.co.za/en/images/Afrox_Annual_IR_2019_tcm266-593671.pdf.

African Rainbow Minerals, 2019, 2019 Integrated annual report, viewed 28 August 2020, from https://arm.co.za/wp-content/uploads/2020/06/2019_intergrated_ annual_report.pdf.

Anglo American Platinum, 2017, Integrated report 2017, viewed 28 August 2020, from https://www.angloamericanplatinum.com/ /media/Files/A/Anglo-AmericanGroup/Platinum/report-archive/2017/anglo-platinum-integrated-report-2017.pdf.

ArcelorMittal, 2016, Integrated annual report 2016, viewed 28 August 2020, from https://www.arcelormittal-reports.com/reports/integrated-2016/pdf/fullintegrated.pdf.

Azapagic, A., 2004, 'Developing a framework for sustainable development indicators for the mining and minerals industry', Journal of Cleaner Production 12(6), 639-662, viewed 04 May 2020, from https://doi.org/10.1016/S0959-6526(03)00075-1

Barnabe, F., Giorgino, M. \& Kunc, M., 2019, 'Visualizing and managing value creation through integrated reporting practices: A dynamic resource-based perspective', Journal of Management and Governance 25, 537-575, viewed 26 August 2020 from https://doi.org/10.1007/s10997-019-09467-z

Barney, J., 1991, 'Firm resources and sustained competitive advantage', Journal of Management 17(1), 99-120, viewed 26 August 2020, from https://doi. org/10.1177/014920639101700108

BHP Billiton, 2019, BHP annual report 2019, viewed 04 May 2020, from https://www. bhp.com/investor-centre/annual-report-2019.

Bowman, C. \& Ambrosini, V., 2000, 'Value creation versus value capture: Towards a coherent definition of value in strategy', British Journal of Management 11(1), 1-15, viewed 26 August 2020, from http://doi.wiley.com/10.1111/1467-8551.00147

Burcă, V. \& Cilan, T., 2016, 'Business excellence assessment from an integrated reporting perspective', Journal of Economics \& Business Research 22(2), 91-114.

Cheng, M., Green, W., Conradie, P., Konishi, N. \& Romi, A., 2014, 'The International integrated reporting framework: Key issues and future research opportunities', Journal of International Financial Management and Accounting 25(1), 90-119, viewed 26 August 2020, from https://doi.org/10.1111/jifm.12015

Cho, C.H. \& Patten, D.M., 2007, 'The role of environmental disclosures as tools of legitimacy: A research note', Accounting, Organizations and Society $32(7-8)$, 639-647, viewed 18 August 2020, from https://doi.org/10.1016/j. aos.2006.09.009

Christian, J., 2016, 'Differences between environmental disclosures in various corporate reports', unpublished Masters dissertation, University of Pretoria.

Dalbøl, J.P. \& Dalbøl, M.L., 2011, 'Sustainability and value creation', Masters thesis, Copenhagen Business School.

De Villiers, C. \& Alexander, D., 2014, 'The institutionalisation of corporate social responsibility reporting', British Accounting Review 46(2), 198-212, viewed 28 August 2020, from https://doi.org/10.1016/j.bar.2014.03.001

Exxaro Resources, 2018, Exxaro Resources Integrated Report 2018, viewed 03 May 2020, from https://www.exxaro.com/investor/integrated-reports2018/pdf/fullintegrated.pdf.

Farneti, F. \& Guthrie, J., 2009, 'Sustainability reporting by Australian public sector organisations: Why they report', Accounting Forum 33(2), 89-98, viewed 3 May 2020, from https://doi.org/10.1016/j.accfor.2009.04.002

Flower, J., 2015, 'The international integrated reporting council: A story of failure', Critical perspectives on Accounting 27, 1-17, viewed 28 August 2020, from https://doi.org/10.1016/j.cpa.2014.07.002

Freeman, R.E., 2001, 'A stakeholder theory of modern corporations', in T.L. Beauchamp \& N.E. Bowie (eds.), Ethical theory and business, pp. 56-65, Prentice-Hall, Upper Saddle River, NJ.

Freudenreich, B., Ludeke-Freund, F. \& Shaltegger, S., 2019, 'A stakeholder theory perspective on business models: Value creation for sustainability', Journal of Business Ethics 116, 1-16, viewed 26 August 2020, from https://doi.org/10.1007/ susiness Ethics 116,

Glassman, D., Potoski, M. \& Callery, P., 2017, 'Missing metrics that matter to investors: How companies can develop ESG financial value creation metrics', The Journal of Environmental Investing 8(1), 206-221, viewed 3 May 2020, from https://doi. Environmental Investing 8
org/10.2139/ssrn.3520685

Gokten, S. \& Gokten, P. 2017, 'Value creation reporting: Answering the question "value to whom" according to the International Integrated Reporting Framework', Zeszyty Teoretuczne Rachunkowsci 91(147), 145-169, viewed 3 May 2020, from https://doi.org/10.5604/01.3001.0009.8028

Gold Fields, 2019, Integrated Annual Report 2018, viewed 3 May 2020, from https:// www.goldfields.com/reports/annual-report-2018/pdf/full.pdf.

Grassman, M. Fuhrmann, S. \& Guenter, T.W., 2019, 'Drivers of the disclosed "connectivity of the capitals": Evidence from integrated reports', Sustainability Accounting, Management and Policy Journal 10(5), 877-908, viewed 25 August 2020, from https://doi.org/10.1108/SAMPJ-03-2018-0086

IFAC, 2020, Understanding value creation, IFAC, New York, NY, viewed 08 July 2020, from https://integratedreporting.org/wp-content/uploads/2013/07/IR-BackgroundPaper-Value.pdf. 
IIRC, 2013, The International <IR> Framework, IIRC, London, viewed 08 July 2020 from https://integratedreporting.org/wp-content/uploads/2013/12/13-12-08the-international-ir-framework-2-1.pdf.

IIRC, 2014, Creating value: Value to the board, IIRC, London, viewed 08 July 2020, from https://integratedreporting.org/wp-content/uploads/2015/04/Value-to-theBoard.pdf.

IIRC, 2017, Creating value: The value of human capital reporting, IIRC, London, viewed 08 July 2020, from https://integratedreporting.org/wp-content/uploads/2017/ 05/CreatingValueHumanCapitalK1.pdf.

Karia, N., 2019, 'Knowledge of value creation and sustainability performance', Medcave Journal of Business Management 2(1), 1-10.

Knight, M., 2002, 'Governance in higher education corporations: A consideration of the Constitution Created by the 1992 Act', Higher Education Quarterly 56(3), 11 viewed 03 May 2020, from https://doi.org/10.1111/1468-2273.00218

Komonen, H., 2019, 'Stakeholder value creation through integrated reporting', Masters thesis, University of Turku.

Lepak, D.P., Smith, K.G. \& Taylor, M.S., 2007, 'Value creation and value capture: A multilevel perspective', Academy of Management Review 32(1), 180-194, viewed 03 May 2020, from http://journals.aom.org/doi/10.5465/amr.2007.23464011.

Lev, B. \& Sunder, S., 1979, 'Methodological issues in the use of financial ratios', Journa of Accounting Economics 1(3), 187-210, viewed 03 May 2020, from https://doi. of Accounting Economics 1 (3)

Lonmin, 2016, Annual Report and Accounts 2016, viewed 03 May 2020, from https:// www.google.com/url?sa $=t \& r c t=j \& q=\& e s r c=s \&$ source $=$ web $\& c d=\& v e d=2 a h U K E w$ ojseGh KrtAhUNURUIHd AD IQFjAAegQIARAC\&url=https $\% 3 \mathrm{~A} \% 2 \mathrm{~F} \% 2 \mathrm{Fthevault}$ exchange $\% 2$ F\% $\%$ Fget group doc\%3D166\%2F1482416123-lonmin-annualreport-and-accounts-2016.pdf\&usg=AOvVaw1t5fzWATpu5jNyaGXg9P_n.

Maubane, P., Prinsloo, A. \& Van Rooyen, N., 2014, 'Sustainability reporting patterns of companies listed on the Johannesburg Securities Exchange', Public Relation Review 40, 153-160, viewed 21 August 2020, from https://doi.org/10.1016/j pubrev.2014.02.014

Pan African Resources, 2015, Integrated Annual Report 2015, viewed 03 May 2020, from https://www.panafricanresources.com/wp-content/uploads/Pan-AfricanResources-PLC-IAR-2015.pdf.

Porter, M.E., 1980, Competitive strategy: Techniques for analyzing industries and competitors, Free Press, New York, NY.

Porter, M.E., 1989, 'From competitive advantage to corporate strategy', in D. Asch \& C. Bowman (eds.), Readings in strategic management, pp. 234-255, Palgrave, London, viewed 25 August 2020, from http://link.springer.com/10.1007/978-1349-20317-8_17.
Porter, M.E. \& Kramer, M.R., 2019, 'Creating shared value', in G. Lenssen, \& N. Smith (eds.), Managing sustainable business, pp. 323-346, Springer, Dordrecht, viewed 21 August 2020, from http://link.springer.com/10.1007/978-94-024viewed 21 .1144-7.

Ramaswamy, V. \& Ozcan, K., 2013, 'Strategy and co-creation thinking', Strategy and Leadership 41(6), 5-10, viewed 21 August 2020, from https://www.emerald.com/ insight/content/doi/10.1108/SL-07-2013-0053/full/html

Sacui, V. \& Dumitru, F., 2014, 'Market-based assets. Building value through marketing investments', Procedia - Social and Behavioral Sciences 124, 157-164, viewed 21 August 2020, from https://linkinghub.elsevier.com/retrieve/pii/S1877042 814020205

Schoenmaker, D. \& Schramade, W., 2019, 'Investing for long-term value creation', Journal of Sustainable Finance and Investment 9(4), 356-377, viewed 21 August 2020, from https://doi.org/10.1080/20430795.2019.1625012

Sheveleva, E., 2018, 'Value concepts and value creation model in integrated reporting', Review of Business and Economics Studies 6(2), 30-43, viewed 03 May 2020, from https://doi.org/10.26794/2308-944X-2018-6-2-30-43

Śledzik, K., 2013, 'Financial and non-financial value drivers in shareholder value creation process', SSRN Electronic Journal April, 89-97, viewed 05 May 2020, from https://doi.org/10.2139/ssrn.2257767

Sofian, I., 2018, 'Approaching value creation from an integrated reporting perspective', paper presented at the 6th International Scientific Conference IFRS: Global Rules and Local Use, 11th-12th October 2018, Prague, pp. 247-260.

Sunder, S., 2017, 'Value creation, distribution, and integrated reporting', Value and Integrated Financial Reporting 5(24), 1-28, viewed 21 August 2020, from https:// doi.org/10.2139/ssrn.2964950

Titko, J. \& Shina, I., 2017, 'Non-financial value drivers: Case of Latvian banks', Procedia Engineering 178, 192-199, viewed 21 August 2020, from https://doi.org/10.1016/j. proeng.2017.01.095

Wernerfelt, B., 1984, 'A resource-based view of the firm', Strategic Management Journal 5(2), 171-180, viewed 21 August 2020, from https://doi.org/10.1002/ smj.4250050207

Wesizwe Platinum, 2014, Integrated Annual Report 2014, viewed 03 May 2020, from https://www.wesizwe.co.za/cmsAdmin/uploads/integrated-annual-report-201430-03-2015_001.pdf.

Windsor, D., 2017, 'Value creation theory: Literature review and theory assessment', Stakeholder Management Business and Society 1, 75-100, viewed 21 August 2020, from https://doi.org/10.1108/S2514-175920170000004 